\title{
Can Trademark Infringement Be a Victimless Crime? The Stone Creek v. Omnia Case
}

\author{
Doug Bania \\ Nevium Intellectual Property Consultants, San Diego, CA, USA \\ E-mail: dougbania@nevium.com
}

Received: November 16, 2018

Accepted: December 7, 2018

Online Published: December 13, 2018

doi:10.11114/ijlpa.v1i2.3879

URL: https://doi.org/10.11114/ijlpa.v1i2.3879

\begin{abstract}
This article examines a case in which the defendants had made unauthorized use of the plaintiff's trademark but were nonetheless able to successfully defend themselves against the awarding of monetary damages. As it shows, to claim damages, trademark holders must demonstrate actual harm to their reputation or loss of potential profits. It describes the methods used by the author to determine the actual effect of the infringement, which included analyzing information regarding the defendants' intentions and the parties' industry and the findings of a consumer survey and of Internet search and social media analytic tools. The article argues for the importance of understanding the particularities of a given case and marketplace and the utility of readily available and inexpensive Internet analytic tools.
\end{abstract}

Keywords: trademark infringement, consumer awareness, Internet analytic tools

\section{Introduction}

The protection of trademarks is a cornerstone of U.S. intellectual property law. Yet trademark infringement, even when undisputed, does not necessarily merit the awarding of monetary damages. Even the knowing or willful use of someone else's trademarks is not alone sufficient to prove actual harm, an intent to deceive consumers or deprive trademark holders, or the right to damages. To claim damages, trademark holders must demonstrate not simply unfair or unauthorized use of the mark but actual damage to their reputation or loss of potential profits. Conversely, to defend against such claims, parties sued for damages must be able to demonstrate that the accusing party suffered no such actual harm.

To demonstrate the complex factors that are relevant to such disputes and several ways in which damages might be determined and assessed, this article examines a case, Stone Creek, Inc. v. Omnia Italian Design, in which the defendants did not dispute the unauthorized use of the plaintiff's trademark but were nonetheless able to successfully defend themselves against the awarding of monetary damages. It describes the methods used by the author, a consultant with extensive experience analyzing and valuing intellectual properties and intangible assets, to investigate the alleged trademark infringement and determine the actual effect of said infringement upon the parties' reputation and profits. As it will show, these methods included gathering and analyzing information regarding the defendants' intentions, the furniture industry, and the actual impact of the infringement. In particular, it describes the findings of a consumer survey and of Internet search and social media analytic tools that appear to have had the greatest impact upon the judge's eventual ruling.

\section{Background}

The plaintiff in this case, Stone Creek, Inc., designs, develops, markets, and sells furniture and related kitchen and bath improvements through showrooms in Phoenix, Chandler, and Glendale, Arizona. In its complaint, it accused Omnia of attaching its Stone Creek trademark to furniture it supplied to Bon-Ton Stores and Bon-Ton Stores of selling those products in its furniture galleries, thereby profiting from Stone Creek's intellectual property and reputation without permission or paying a licensing fee. As is typical in such cases, Stone Creek's legal team argued that the value that the plaintiff had developed in the trademark was "being irreparably harmed and diluted" and that its use by the defendants had "caused significant confusion to Plaintiff's customers and damage to Plaintiff's goodwill, value, and reputation" (Stone Creek v. Omnia, 2013).

The first defendant in this case, Omnia Italian Design, is a California-based manufacturer and distributor of leather furniture with showrooms in California, Texas, North Carolina, and Nevada. Although it sells its products to retailers 
around the country, Omnia does not operate retail locations or sell furniture directly to consumers. In 2003, Omnia had entered into an agreement with Stone Creek to manufacture furniture that the Arizona company sold under its own trademark. According to Stone Creek's complaint, in 2008 Omnia began selling products to Bon-Ton that also carried the name "Stone Creek Leather." According to the complaint, Bon-Ton sold this furniture between 2008 and 2013, which Stone Creek discovered in 2013 from consumers visiting their retail store and an inquiry from a customer concerning a warranty issue. When they contacted the president of Omnia in response to this information, he admitted to the use of the trademark, and following this complaint, Omnia and Bon-Ton changed the name of the furniture being sold under the Stone Creek name to Red Canyon.

The other defendant in this case, Bon-Ton Stores, Inc., was at the time a national retailer with operations in 26 states. The 271 stores it operated under seven nameplates-Bon-Ton, Carson's, Younkers, Elder-Beerman, Boston Store, Herberger's, and Bergner's-included separate furniture galleries under the first five of those names. According to information provided by the corporation and depositions taken from several of its executives, its primary customers were middle- to upper-class women between the ages of 25 and 60 with annual incomes between $\$ 55,000$ and $\$ 125,000$. In the 4 years preceding the complaint, Bon-Ton had earned roughly $\$ 3$ billion in revenue and spent approximately $\$ 130$ million annually on marketing a variety of goods, including apparel as well as home goods. At the time, home goods, including furniture, accounted for approximately $17 \%$ of Bon-Ton's sales.

\section{Willful Intent to Benefit from the Stone Creek Marks}

To analyze whether Omnia had willfully or intentionally sought to benefit from use of the Stone Creek marks, I reviewed depositions from the furniture buyer at Bon-Ton and the manufacturer's representative who had arranged the purchase of the accused furniture from Omnia and conducted interviews with two Omnia officers. I had been advised by counsel that the proper standard by which to assess willful infringement was whether the alleged infringer intentionally sought to trade on another's good will or to trade on the established name of another. I interpreted this to be synonymous with the intent to "coattail" on the good will or reputation of another and a desire to gain from the reputation that another had built and therefore capture sales that the infringer would not have gained had they used their own reputation or goodwill in lieu of another's.

What I discovered as a result of this data gathering was that Omnia and Bon-Ton had reached an agreement that Omnia would provide leather furniture for Bon-Ton to sell in their retail stores before those parties had jointly decided to use the Stone Creek trademark on the furniture in question. This review of information revealed that Bon-Ton had wanted to market the furniture under a private label that would be exclusive to them and that Omnia had suggested the name "Stone Creek" for this purpose largely for reasons of convenience, as the name had already been printed on some of their marketing materials and SKU numbers connected to the term were already programmed into their inventory system. Ultimately, however, Omnia and Bon-Ton had made a shared decision to use the name "Stone Creek" because it sounded American-made. The officials from Omnia and Bon-Ton who were interviewed and deposed all recalled that the term had been selected primarily for its invocation of a western American image or style rather than to Stone Creek, Inc. In fact, the furniture buyer at Bon-Ton testified that she had not been aware that the Stone Creek furniture company even existed until the issue of trademark infringement was raised in 2013 and the decision was made to change the name.

This seeming lack of intent to trade on Stone Creek's goodwill was also supported by the evidence from the Cowan report and my own analysis of Internet data discussed below, which demonstrated virtually no awareness of Stone Creek as a furniture brand name outside of Arizona. Together, the preponderance of the evidence suggested that there was no reason for Omnia or Bon-Ton to intentionally select the Stone Creek marks to trade on the plaintiff's goodwill, as Stone Creek appears to have had no goodwill within Bon-Ton's trading territory on which to "coattail."

\section{Contribution of the Stone Creek Trademark to Retail Sales of Accused Furniture}

To analyze the impact of the Stone Creek marks to the accused sales by Bon-Ton to its customers, I reviewed the following three main sources of information: (1) the results of a consumer opinion survey conducted by an outside expert, (2) industry information on trends and factors that typically contribute to retail sales of furniture, and (3) statistics regarding Internet searches and social media related to key names and terms in this case.

\subsection{Consumer Awareness Survey Report}

I began my analysis by reviewing a report based on a consumer awareness survey also commissioned by the defendants' counsel and conducted and analyzed by Charles D. Cowan, a nationally recognized expert, using a commonly accepted statistical methodology for the measurement of consumer recognition. For this analysis, Cowan determined the geographical boundaries of what he termed Bon-Ton's trading territory, hereafter referred to as the BTTT, which included all the zip codes in which Bon-ton had sold furniture identified with the Stone Creek trademark, an area that covered most of Illinois, Indiana, Wisconsin, Pennsylvania, Ohio, and Michigan. He then designed and tested a 16-question 
questionnaire regarding furniture purchases, which was then sent to potential respondents from the American Consumer Opinion Panel (ACOP) living in a random sample of the targeted zip codes. After screening for eligibility and possible bias, this search yielded a sample of 402 respondents, providing a $95 \%$ confidence interval.

The results showed that more than half of the surveyed consumers from the BTTT had shopped for furniture in the previous 13 months; among those, $6.5 \%$ reported having purchased leather furniture, and of those, three-fourths said they could name the brand. More than $60 \%$ of the respondents, and $68 \%$ of those who had purchased leather furniture, reported having seen print ads for leather furniture in the previous year. These data suggest that the respondents represented consumers knowledgeable about furniture shopping and leather furniture. Although most could name several specific media outlets where they had seen such ads, none mentioned Phoenix Home \& Garden, the specific marketing vehicle identified by Stone Creek, Inc. in their complaint, indicating that it appeared to have no impact in creating name recognition in that area.

When asked if they could name brand names for leather furniture, $31 \%$ of the respondents were able to name one or more brands. Of these, none spontaneously mentioned Stone Creek as a brand. The survey then presented respondents with a list of names it claimed were brand names of furniture and asked them to identify all names with which they were familiar. Although 47 consumers identified Stone Creek as a furniture brand, nearly as many selected a name of a jewelry company, a made-up name, or "none of these," which suggests that many were simply guessing. Based in these results, the analyst concluded that only $1.7 \%$ of the responding consumers recognized the name Stone Creek in relation to furniture. When the consumers who claimed to recognize Stone Creek as a brand of furniture were asked to select where a consumer could buy Stone Creek furniture from a list of possible outlets, approximately half selected a Stone Creek store, though most of these also identified other retailers as well, including Bon-Ton stores. Only one, or less than one quarter of one percent, of the respondents responded that Stone Creek furniture could be purchased in Arizona, indicating a nearly complete lack of recognition of the plaintiff's trademark.

Based on this evidence, the Cowan report concluded that neither the plaintiff's trade nor its reputation had penetrated Bon-Ton's trading territory, and thus that the defendants had not traded on the plaintiff's reputation or goodwill by using the name "Stone Creek" on furniture sold by Bon-Ton Stores. Since consumers in the BTTT recognized no apparent connection between leather furniture and Stone Creek, Inc., the consumers who purchased the Stone Creek furniture at Bon-Ton likely did not do so because of a perceived affiliation of that furniture with the Stone Creek furniture sold in Arizona.

\subsection{Nature of the Furniture Industry}

As I learned more from my informants at Omnia and Bon-Ton and from industry research about the factors that influenced furniture purchasing decisions at the time that the infringement began, a trend quickly emerged: In the furniture industry, local is king. Practical considerations such as the size and weight of furniture and the cost to ship large pieces have naturally created a furniture market in which consumers depend on retail outlets within driving distance from their homes. We also found that consumer decisions about furniture are heavily biased toward having hands-on access to their potential purchases. Being able to feel the leather against their skin or see a suite of furniture in its full glory on the showroom floor goes a long way toward encouraging a customer to invest in a nice living room piece. Our analysis revealed that instead of trademark recognition, factors such as price, durability, style, and convenient delivery to the home reign supreme in the furniture industry, and that a name, logo, or word indicating the manufacturer or source of origin has little impact on customer behavior in this marketplace.

According to a 2007 Furniture Today report, nearly half of 2006's \$83 billion in U.S. furniture sales occurred at retail locations identified as traditional furniture stores, such as Bon-Ton's furniture galleries, while just 7\% of sales took place at retail locations identified as single-source networks, such as Ethan Allen or Stone Creek (French, 2007). (Another 7\% took place at discount department stores, the rest at lifestyle furniture stores and other distribution channels.) According to a consumer opinion survey conducted by Furniture Today and HGTV, the factors that influence a consumer's decisions on where to purchase a sofa included selection, familiarity with a retailer, nearness to home or office, price, quality, and service; of these, the most important factor was a retail store's reputation (Furniture Today, 2008). Together, the industry information I reviewed identified four main influences on consumers' decision when selecting a piece of furniture: price, quality, durability, and style/design. None of the factors identified by these sources included trademarks used to identify the manufacturer of furniture products. This finding would seem to be supported by the fact that the Omnia furniture carried by Bon-Ton continued to sell well after its name was changed to Red Canyon.

In summary, the information available to me suggested that consumers make their decisions on whether to purchase a sofa or other furniture based more on product features and the reputation of the retailer than on names or trademarks that provide an association to a manufacturer. Thus, the preponderance of this evidence indicated that in the furniture industry - with the possible exception of high-prestige products associated with a particular design workshop, such as 
Stickley, or known retailers who sell only their own brand of furniture in their stores, such as Ethan Allen - the influence of trademarks on a piece of furniture upon consumers' purchasing behavior is so negligible as to be virtually non-existent, given the many factors and other considerations that furniture manufacturers and retailers must manage.

\subsection{Internet Search and Social Media Use}

According to what I learned from the Cowan report and my human sources and consistent with this retail furniture business model, Stone Creek's marketing channels were limited to its showrooms and local delivery in the Phoenix, Arizona, area, while Omnia's marked products were sold only to customers within 200 miles of the Bon-Ton furniture galleries spread out across several midwestern and eastern states. Given the available evidence, it appeared that the two territories never overlapped, and in fact were separated by more than 1,000 miles at their closest point. But in the age of the Internet, were these parties' customer bases truly as separate as they seemed? To find out, I conducted an in-depth Internet and social media analysis.

Even though few consumers buy furniture — especially large, expensive pieces of furniture such as a leather sofa—over the Internet, many begin or supplement their quest for such purchases with a Google search, and the terms they use in these searches can provide useful information about consumers' brand and trademark awareness. To analyze this search behavior, I turned to AdWords, an easy-to-use Google online advertising program (now called Google Ads) intended to help users reach new customers. In particular, one of its free tools, the Keyword Planner, provides advertisers with information on how often users search for a particular term and the cost per click that Google would charge an advertiser for a click-through to their website for that term. The tool also allows potential advertisers to determine the potential cost on a global scale or for a designated geographical region or locale. For this analysis, I used Google's Keyword Planner to compare users' awareness of furniture manufacturers and of furniture retailers as measured by the average number of monthly searches for specific search terms and regional awareness of the terms "Stone Creek Furniture" and "Bon-Ton."

To determine the relative recognition of various furniture trademarks, I first searched the term "Quality Sofa Brands," which turned up a website, sofaandsectionals.com, that provided a list of the names used by more than 50 major sofa providers. I then used the Keyword Planner to perform an analysis of all the listed names. This analysis showed that at the time of this analysis, the average monthly number of searches for the individual names ranged from 70 to 27,100 , with a mean of 3,606 and a median of 1,100 .

To compare this volume of searches by furniture trademarks to that of searches by places where furniture could be purchased, I then also performed this task for 28 furniture retailers, 6 discount retailers, and 7 national retailers. Based on these results, I found that the names of national retail companies received more search activity than names of either furniture retailers or furniture companies, and that names of furniture retailers generated more search activity than names of furniture companies. This analysis showed, in other words, that the less common use of names of furniture manufacturers in AdWords advertising reflected lower consumer awareness of the names of furniture manufacturers than the names of furniture retailers and retail companies. This seemed to support the general wisdom in the industry that furniture consumers were influenced more by the reputation of the retailers from whom they bought furniture than by the reputation of the manufacturers who produced that furniture.

Given what I had learned about the separate geographical areas in which Stone Creek, Inc. and Bon-Ton Stores marketed and sold their furniture, I also analyzed the names "Bon-Ton" and "Stone Creek Furniture" on both a national and stateby-state level. On a national level, I found that the term "Bon-Ton" was searched an average of 110,000 times per month, while the term "Stone Creek Furniture" was searched an average of just 1,300 times per month. These figures thus indicate much greater consumer awareness of the Bon-Ton name than of the Stone Creek name. These national-level findings were supported by a simple analysis I conducted of the two companies' social media presence. As might be expected given the relative size of the two companies, Bon-Ton's social media pages were viewed and followed by many more potential consumers, as demonstrated by Bon-Ton's having received 221,529 Facebook Likes compared to Stone Creek's 910. I also found that Bon-Ton had nearly 10 times the number of Twitter followers, more than 50 times the number of Pinterest followers, and nearly 8 times the number of YouTube Subscribers.

I next conducted an analysis of the search statistics for the two names on a state-by-state basis, which indicated little search activity for either company's name in the other's geographical area. According to these data, more than $96 \%$ of the searches for "Stone Creek Furniture" originated from states outside the BTTT. It should be noted, however, that this probably means that far fewer than $4 \%$ of these searches originated from BTTT states because Google analytics rounds search data to the nearest 10, meaning that as few as 1 or 2 searches would register as 10 . And in fact, a closer inspection showed that not a single state in the BTTT reported more than 10 searches, which likely means that there may have been considerably fewer than 10. In short, an examination of the specific analytics showed virtually no searches for Stone Creek in the BTTT. As would be expected, Arizona was the source of the largest number of searches for this term, with 25 times the number of searches than those originating from the second most common state, California. Within the BTTT, 
in contrast, the term "Bon-Ton" had been searched 53,329 times, compared to no more than 50 searches (and perhaps as few as 5) for "Stone Creek Furniture." Searches for the two companies' names appeared to reflect the non-overlapping geographical areas of their stores and further supported the conclusion that Bon-Ton consumers were unlikely to have been aware of the name "stone creek" as used with furniture products.

In sum, based on the consumer awareness survey results in the Cowan Report, research into factors that typically contribute to the retail sale of furniture, and my analysis of Internet search and social media statistics, I found no evidence that Bon-Ton (and thus Omnia) benefited from use of the Stone Creek trademarks in its sale of sofa products to retail consumers.

\section{Final Ruling}

The judge's final ruling in this case was consistent with the conclusions of my analysis and report as summarized above. Although he found that "Omnia knew of Stone Creek's use of the mark at the time Omnia offered it for Bon-Ton's private label" and that "Omnia copied the STONE CREEK mark from materials provided to it by Stone Creek" without asking for permission and "with full knowledge of Stone Creek's senior use," he ruled that "Omnia did not choose the mark with the intent of trading off Stone Creek's goodwill" (Stone Creek v. Omnia, 2015).

His decision was clearly based in part on accepting the defendants' account that the charged infringement had been unintentionally initiated by Bon-Ton's request for a private label under which to sell Omnia's products to avoid price comparisons and competition with Omnia's other clients and for an "American made name," in response to which Omnia produced a list of possible names, including Stone Creek, from which Bon-Ton made their selection. He was also apparently convinced that Omnia had suggested the mark because it already had the logo and marketing material available and that Bon-Ton had selected the mark because of its American associations-neither of which showed any intent to trade off of Stone Creek's goodwill.

But the crux of his final decision that the defendants had not profited from the plaintiff's goodwill was based on the evidence presented that Stone Creek, Inc. had not earned any such goodwill in Bon-Ton's trading territory. He reiterated that that virtually all of Bon-Ton's furniture sales were to purchasers living within 200 miles of its furniture galleries in Illinois, Wisconsin, Pennsylvania, Ohio, and Michigan, which also included portions of Iowa and Indiana. The available information showed that Stone Creek, in contrast, sold almost all of its products in Arizona and three other western states, where it directed all of its marketing and where Bon-Ton did not engage in direct marketing.

Thus, although the court found that the gross revenues from sales of the accused furniture were nearly $\$ 4.5$ million, the court awarded Stone Creek no monetary damages. Citing precedent to explain his ruling, the judge ruled that the core element of trademark infringement is the "likelihood of confusion" (Mattel v. MCA Records, 2003; Network Automation v. Advanced Systems, 2011). Therefore, to make a case for damages, a plaintiff must show not only that infringement took place but "that the defendant's use of its trademark 'is likely to cause confusion, or to cause, mistake, or to deceive" (Fortune Dynamic v. Victoria's Secret, 2010) and to do so for a "reasonably prudent consumer" (Murray v. Cable National Broadcasting, 1966; Dreamwerks v. SKG Studio, 1998) and therefore for an appreciable number of people (Falcon Stainless, Inc. v. Rino, 2014). Using the factors for assessing confusion set out in Sleekcraft (AMF v. Sleekcraft Boats, 1979), the judge found no evidence of actual confusion and ruled that the likelihood of confusion was diminished by the parties' having distinct local marketing channels and consumers' likelihood of exercising greater care given the expense involved in purchasing furniture. ${ }^{1}$

\section{Conclusion}

A trademark functions to identify the source of a product, serving as an indicia of source. What this case underlines, however, is that a trademark has little utility for its user if the relevant consumer base does not make an association between that trademark and a given product being sold under that mark. Furthermore, it reveals, the influence of a trademark can vary considerably according to its relevance to the features that most influence consumer behavior in a given industry. And as the final ruling in this case demonstrates, even conscious and willful infringement does not necessarily entitle a trademark owner to damages. Rather, the reputational and monetary damages suffered by a plaintiff must be demonstrated and quantified.

Yet the goodwill or prestige associated with a product is nebulous and difficult to demonstrate or quantify, as it requires insight into motivations of both those doing the infringing and the consumers who buy the infringing products and into the likely impact of a trademark on consumer behavior within a given marketplace. As this case points out, whereas intent may be determined by collecting testimony and written evidence, determining impact requires information that is more difficult to uncover and analyze. As with the consumer awareness report conducted for this case, gathering information from actual or possible consumers about a product that will support one's case can be very time-consuming, difficult, and expensive. In contrast, the Internet search and social media analytic tools that I employed for this analysis can offer a 
quicker, easier, and less expensive way to gather pertinent data for such cases. That the judge's ruling repeatedly cited evidence from that analysis to support his finding that Stone Creek had suffered no actual damages from this infringement upon its trademark indicates that this non-traditional approach to measuring the impact of trademarks and confusion made a legitimate and crucial contribution to resolving the dispute. In this particular case, data readily available to anyone through Google's Keyword Planner tool was able to clarify the economic impact of a trademark in a way that appeared to be at least as powerful and persuasive as more traditional survey and anecdotal evidence. In addition to its potential usefulness to consultants such as myself, companies and their legal advisors might also avail themselves of such information before deciding whether to file an expensive and potentially unsuccessful lawsuit.

Beyond the specific methods employed, this case also argues for the importance of understanding potential differences in consumer preferences and behavior when considering various kinds of purchases. It suggests, for instance, that a trademark might have a more powerful influence on consumers' choices when purchasing less expensive and less durable goods or goods available from a larger set of sources. It may also indicate that some trademarks might function as more obvious indicators of source than others, given the judge's acceptance of the defendants' argument that they viewed "stone creek" as primarily a descriptive or evocative term rather than a reference to a recognized manufacturer-a point he underlined by noting that searches for "stone creek" also revealed a number of other products and entities being marketed using that name. The fact that Stone Creek's logo consisted of its name in a fairly conventional font within a simple oval may have also weakened the company's argument that the trademark was an inherently distinctive intellectual product.

Ultimately, then, this case proves once again that there is no such thing as a one-size-fits-all definition of actionable trademark infringement or a single effective strategy for demonstrating and quantifying monetary damages for such infringement. Instead, it demonstrates the importance of understanding the particularities of an individual case and of a given industry and market and the utility of readily available and inexpensive Internet analytic tools.

\section{References}

AMF v. Sleekcraft, 599 F.2d 341, 348-49 (9 $9^{\text {th }}$ Cir. 1979).

Dreamwerks v. SKG Studio, 142 F.3d 1127, 1129 ( $9^{\text {th }}$ Cir. 1998).

Falcon Stainless v. Rino, 572 Fed App'x 483, 486 ( $9^{\text {th }}$ Cir. 2014).

Fortune Dynamics v. Victoria's Secret, 618 F.3d 1025, 1030 ( $9^{\text {th }}$ Cir. 2010).

French, D. (2007). Channel surfing: Traditional furniture stores. Furniture Today, March 26.

Furniture Today. (2008). Consumer views: Spotlight on sofas. Furniture Today, April 7.

Mattel v. MCA Records, 353 F.3d 792, 806 ( $9^{\text {th }}$ Cir. 2003).

Murray v. Cable National, 86 F.3d 858, $861\left(9^{\text {th }}\right.$ Cir. 1996).

Network Automation v. Advanced Systems, 638 F.3d 1137, 1149 ( $9^{\text {th }}$ Cir 2011).

Stone Creek v. Omnia, 862 F.3d 1131, 1133 (9 $9^{\text {th }}$ Cir. 2017).

Stone Creek v. Omnia, No. CV-13-00688-PHX-DLR (D Ariz, 2015).

Stone Creek v. Omnia, Case 2:13-cv-00688-NVW (D Ariz, 2013).

\section{Notes}

Note 1. Although the Ninth Court of Appeals later reversed portions of the District Court's ruling, challenging its interpretation of Sleekcraft, it agreed that the infringement did not merit financial damages (Stone Creek v. Omnia, 2017).

\section{Copyrights}

Copyright for this article is retained by the author(s), with first publication rights granted to the journal.

This is an open-access article distributed under the terms and conditions of the Creative Commons Attribution License which permits unrestricted use, distribution, and reproduction in any medium, provided the original work is properly cited. 